\title{
IMPLEMENTASI PENDIDIKAN DAN PELATIHAN DALAM MENINGKATKAN KOMPETENSI GURU (STUDI KASUS PADA UPT SMP NEGERI 2 DUAMPANUA KABUPATEN PINRANG)
}

\author{
Muh Nur Rasyid \\ muhnurrasyid@unismuh.ac.id \\ Fakultas Ekonomi dan Bisnis \\ Universitas Muhammadiyah Makassar \\ Andi Nurqalbiani \\ andinurqalbiani@gmail.com \\ Fakultas Ekonomi dan Bisnis \\ Universitas Muhammadiyah Makassar
}

\begin{abstract}
The purpose of this study is to analyze the training needs, to find out in setting training objectives, to find out the training curriculum development, to find out the preparation of education and training, to know the implementation of education and training, to find out training evaluation in improving teacher competence. This type of research is descriptive qualitative, data collection techniques used observation, interviews, and documentation. Sources of data are the Principal, Deputy Principal and teachers at UPT SMP Negeri 2 Duampanua. The results of this study indicate that the implementation of education and training in improving teacher competence in UPT SMP Negeri 2 Duampanua is carried out through 6 stages of education and training which include; (1) training needs analysis (Taining Need Assessment), (2) setting training objectives, (3) curriculum development, (4) preparation of training, (5) implementation of education and training, (6) evaluation, basically it has been done quite well it's just that there are deficiencies in terms of evaluation, the training evaluation conducted by UPT SMP Negeri 2 Duampanua is not sustainable and the implementation is only at the training venue, and is not accompanied by follow-up on how the application of the capabilities that have been obtained in the effort to utilize those capabilities is really controlled professionally.
\end{abstract}

Keywords: Education, Training and Teacher Competence

\begin{abstract}
Abstrak
Tujuan dari penelitian ini yaitu untuk mengetahui menganalisis kebutuhan diklat, untuk mengetahui dalam menetapkan tujuan diklat, untuk mengetahui pengembangan kurikulum diklat, untuk mengetahui persiapan pelaksanaan diklat, untuk mengetahui pelaksanaan diklat, untuk mengetahui evaluasi diklat dalam meningkatkan kompetensi guru. Jenis penelitian ini adalah deskriptif kualitatif, teknik pengumpuan data yang digunakan observasi, wawancara, dan dokumentasi.Sumber data adalah Kepala sekolah, Wakil Kepala sekolah dan guru di UPT SMP Negeri 2 Duampanua. Hasil penelitian ini menunjukan bahwa implementasi pendidikan dan pelatihan dalam meningkatkan kompetensi guru di UPT SMP Negeri 2 Duampanua dilakukan melalui melalui 6 tahapan pendidikan dan pelatihan yang meliputi yaitu; (1) analisis kebutuhan pelatihan (Taining Need Assessment), (2) menetapkan tujuan pelatihan, (3) pengembangan kurikulum, (4) persiapan pelaksanaan diklat, (5) pelaksanaan pendidikan dan pelatihan, (6) evaluasi, pada dasarnya hal tersebut telah dilakukan cukup baik hanya saja terdapat kekurangan dalam hal evalusi, evaluasi diklat yang dilakukan oleh UPT SMP Negeri 2 Duampanua tidak berkesinambungan dan penyelenggaraannya hanya ditempat pelatihan saja, dan tidak disertai dengan tindak lanjut bagaimana penerapan kemampuan yang telah diperoleh dalam upaya pemanfaatan kemampuan itu benar-benar dikuasi secara profesional.
\end{abstract}

Kata Kunci : Pendidikan, Pelatihan dan Kompetensi Guru 


\section{PENDAHULUAN}

Pendidikan merupakan sebuah proses pencerdasan kehidupan bangsa yang sekaligus menjadi sarana untuk membangun manusia Indonesia seutuhnya. Keberhasilan pembangunan nasional juga ditentukan oleh kualitas sumber daya manusianya, baik dari segi pengambil keputusan, penentu kebijakan, pemikir maupun perencana, bahkan sampai kepada pelaksana teknis dan pelaku pengawasan pembangunan. Sedangkan sarana yang paling strategis dalam melaksanakan pembangunan nasional tersebut adalah melalui pendidikan, yaitu dengan cara meningkatan kualitas sumber daya manusianya. Akan tetapi, posisi pendidikan yang sangat strategis ini, hanya dapat berarti dan dapat tercapai tujuannya jika peningkatan sumber daya manusianya memiliki sistem yang relevan dengan pembangunan, baik dilihat dari segi kualitas, proses maupun hasilnya.

Pendidikan dalam bentuk, jenis dan ragamnya telah dilaksanakan oleh manusia sepanjang sejarah hidupnya, namun pada kenyataannya, pendidikan yang mampu menghasilkan sumber daya manusia yang berkualitas dan mampu menjawab semua tantangan pada era globalisasi, barangkali belum sepenuhnya terealisasikan. Berbagai nada prihatin akan rendahnya kualitas pendidikan nasional menyadarkan pemerintah dengan melakukan perubahan kebijakan politik dalam ranah sistem pendidikan nasional dimana semangat otonomi sebagai perubahan yang menonjol. Terpuruknya kualitas sumber daya manusia Indonesia sebagai hasil pendidikan merupakan konsekuensi dari kesalahan model pembangunan yang hanya menekankan pada aspek pertumbuhan ekonomi, sementara sektor sosial dianggap sebagai sektor pinggiran yang tidak memberikan sumbangan yang berarti atau bahkan hanya pemborosan terhadap pengeluaran negara. Dampak dari minimnya dana pendidikan bukan hanya terhadap buruknya infrastruktur pendidikan tetapi juga kualitas dan rasio sumber daya manusia guru yang berperan penting dalam pengembangan kualitas pendidikan. Lemahnya pembangunan pendidikan tidak saja berakibat pada kesenjangan kesempatan pendidikan bagi masyarakat tetapi juga rendahnya kualitas sumber daya manusia hasil (output) pendidikan.

Kebijakan pemerintah dalam peningkatan penyelenggaraan pendidikan nasional bisa kita lihat lebih nyata sebagaimana telah disebutkan di atas yaitu dengan disahkannya Undang Undang No. 20 Tahun 2003 tentang Sistem Pendidikan Nasional, kemudian diikuti dengan Undang Undang No. 14 Tahun 2005 tentang Guru dan Dosen serta Peraturan Pemerintah No. 19 Tahun 2005 tentang Standar Nasional Pendidikan. UU dan PP tersebut menunjukkan adanya tuntutan adanya peningkatan kemampuan tenaga pendidik atau guru. Hal ini lebih diperjelas oleh UU No. 14 Tahun 2000 pasal 8-10, yang mensyaratkan dimilikinya kompetensi bagi guru. Oleh karena itu merupakan suatu keharusan bagi guru untuk meningkatkan kompetensinya sesuai standar-standar yang telah ditetapkan oleh pemerintah.

Berdasarkan Uraian tersebut, nampak bahwa salah satu upaya yang perlu mendapat perhatian yang utama dalam meningkatkan kualitas pendidikan adalah peningkatan kualitas guru atau dengan kata lain bahwa sejalan dengan usaha yang telah dilakukan pemerintah sebagai penyedia pendidikan dalam usaha 
peningkatan mutu pendidikan, peningkatan kompetensi guru merupakan hal mutlak yang mesti diperhatikan. Tanpa peningkatan kompetensi guru, maka usaha yang dilakukan pemerintah dalam meningkatkan mutu pendidikan tidak akan berdampak nyata, khususnya dalam kegiatan belajar mengajar dikelas.

Pemerintah semestinya selalu berusaha meningkatkan kompetensi guru secara bertahap, baik melalui penataranpenataran, melanjutkan pendidikan ke jenjang yang lebih tinggi, maupun dengan menggalakkan berbagai workshop dan seminar yang diadakan baik ditingkat pusat, maupun daerah masing-masing. Kegiatan pembinaan guru merupakan bagian yang tak terpisahkan dalam setiap usaha peningkatan mutu pembelajaran. Tantangan yang dihadapi dalam dunia pendidikan semakin kompleks, maka konsekuensinya guru sebagai pelaku utama dituntut untuk meningkatkan peranan dan kemampuannya untuk mengahadapi tantangan tersebut. Berkaitan dengan jabatan dan profesi sebagai seorang guru, fenomena sekarang terlihat di beberapa tempat bahwa masih terdapat guru yang belum memiliki keahlian yang diperolehnya melalui pendidikan dan ditunjukkan dengan sertifikasi atau ijazah dan kata yang sesuai dengan mata pelajaran yang diajarkannya.

\section{Kompetensi}

menyangkut

kewenganan setiap individu untuk melakukan tugas dan mengambil keputusan sesuai dengan perannya dalam organisasi yang relevan dengan keahlian, pengetahuan, dan kemampuan yang dimiliki. Kompetensi yang dimiliki guru harus mampu mendukung pelaksanaan strategi organisasi dan mampu mendukung setiap perubahan yang dilakukan demi terciptanya strategi organisasi dan mampu mendukung setiap perubahan yang dilakukan demi terciptanya keberhasilan suatu organisasi.

Fenomena yang didapatkan penulis pada UPT SMP Negeri 2 Duampanua Kabupaten Pinrang adalah : kurang berkualitasnya hasil pendidikan tidak terlepas dari kelemahan utama dalam proses pembelajaran, yakni adanya kelemahan guru dalam mengemas ataupun mendesain serta membawakan mata pelajaran yang disampaikan kepada peserta didik, disamping itu juga belum maksimalnya proses pendidikan dan pelatihan yang dilakukan di UPT SMP Negeri 2 Duampanua Kabupaten Pinrang dalam meningkatkan kompetensi guru di sekolah tersebut.

Berdasarkan uraian tersebut, peneliti tertarik untuk melakukan penelitian dengan judul "Implementasi Pendidikan dan Pelatihan dalam Meningkatkan Kompetensi Guru (Studi Kasus pada UPT SMP Negeri 2 Duampanua Kabupaten Pinrang).

\section{TINJAUAN PUSTAKA}

\section{Pendidikan dan Pelatihan}

Pendidikan dan pelatihan merupakan kegiatan yang bermaksud memperbaiki dan mengembangkan sikap, prilaku, keterampilan dan pengetahuan para karyawan. Menurut Made Pidarta (1998:109) Pengelolaan sumber daya manusia tentang pendidikan dan pelatihan dimana pada intinya bahwa pelatihan dimaksudkan untuk membantu meningkatkan kemampuan para pegawai dalam melaksanakan tugas sekarang, sedangkan pendidikan lebih berorientasi pada peningkatan kemampuan untuk melaksanakan tugas baru dimana yang akan datang.

Pendidikan (formal) di dalam suatu organisasi adalah suatu proses 
pengembangan kemampuan ke arah yang diinginkan oleh organisasi yang bersangkutan. Menurut Indah Puji Hartatik (2014:38) pelatihan atau training adalah merupakan bagian dari proses pendidikan, yang tujuannya untuk meningkatkan kemampuan dan keterampilan khusus seseorang atau kelompok orang.

Pendidikan pada umumnya berkaitan dengan mempersiapkan calon tenaga yang diperlukan oleh suatu instansi atau organisasi, sedangkan pelatihan berkaitan dengan peningktan kemampuan atau keterampilan karyawan yang sudah menduduki suatu pekerjaan dan tugas tertentu. Suatu pelatihan orientasi atau penekannanya pada tugas yang harus dilaksanakan (job orientation), sedangkan pendidikan lebih pada pengembangan secara umum.

Pelatihan didefinisikan oleh Ivancevich yang dikutip oleh Edi Sutrisno (2007:18), sebagai usaha untuk meningkatkan kinerja karyawan dalam pekerjaan sekarang atau dalam pekerjaan lain yang akan dijabatnya segera.

Menurut Andrew E. Sikula yang dikutip oleh Sadili Samsudin, mendefinisikan pendidikan sebagai berikut, "Development is a longterm educational process utilizing a systematic and organized procedure by wich managerial personnel learn conceptual and theoretical knowledge for general purpose". Pendidikan berbeda dengan pelatihan. Pendidikan lebih bersifat filosofis dan teoritis. Pelatihan merupakan bagian dari pendidikan. Pelatihan bersifat spesifik, praktis dan segera. Pelatihan dimaksudkan untuk memperbaiki penguasaan berbagai keterampilan kerja dalam waktu yang relatif singkat (pendek).
Dari beberapa devinisi tersebut, maka akan terlihat perbedaaan pendidikan dan pelatihan, dimana pelatihan mengandung aspek penyesuaian dan penguasaan berbagai keterampilan dan teknik pelaksanaan kerja tertentu dalam waktu yang relatif singkat, dan umumnya suatu latihan berupaya menyiapkan para karyawan untuk melaksanakan pekerjaan-pekerjaan yang pada saat itu sedang dihadapi. Sedangkan untuk pendidikan lebih terarah kepada kegiatan untuk meningkatkan pengetahuan karyawan termasuk di dalam peningkatan penguasaan teori dan keterampilan memutuskan persoalan-persoalan yang menyangkut kegiatan untuk mencapai tujuan, yang lebih diarahkan kepada tanggungjawab masa mendatang. Meskipun terdapat perbedaan pendidikan dan pelatihan menekankan pada peningkatan kualitas sumber daya manusia dalam mencapai tujuan organisasi, individu dan masyarakat.

\section{Kompetensi Guru}

Guru sebagai salah satu unsur yang menempati kedudukan sangat strategis dan mempunyai banyak peranan di dalam proses belajar mengajar di sekolah. Seperti halnya peran dalam meningkatkan kemajuan belajar siswa maupun dalam mengatasi kesulitan belajar siswa. Khususnya untuk memahami dan menguasai materi pelajaran yang disampaikan guru. Sehingga diharapkan proses beiajar mengajar dapat mencapai hasil yang maksimal sesuai dengan kurikulum yang ada. Untuk mewujudkan keberhasilan tersebut, maka seorang guru harus memiliki kompetensi dalam profesionalisme keguruannya. 
Kompetensi guru mempunyai banyak makna. Sesuai dengan beberapa pendapat, E. Mulyasa mengutip dari pendapat Broke and Stone mengemukakan bahwa kompetensi guru sebagai descriptife of qualitative nature of teacher behavior appears to be entirely meaningful, kompetensi guru merupakan gambaran kualitatif tentang hakikat perilaku guru yang penuh arti.

Menurut Hall dan Jones yaitu pernyataan yang menggambarkan penampilan suatu kemampuan tertentu secara bulat yang merupakan perpaduan antara pengetahuan dan kemampuan yang dapat diamati dan diukur. Richard menyebutkan bahwa istilah kompetensi mengacu kepada prilaku yang dapat diamati, yang diperlukan untuk menuntaskan kegiatan sehari-hari.

Menurut Undang-undang No. 14 tahun 2005 tentang Guru dan Dosen, Kompetensi adalah "seperangkat pengetahuan, keterampilan, dan perilaku yang harus dimiliki, dihayati, dan dikuasai oleh guru atau dosen dalam melaksanakan tugas keprofesionalan".

Sementara pengertian kompetensi menurut Usman sebagaimana yang dikutip Kunandar, kompetensi adalah "suatu hal yang menggambarkan kualifikasi atau kemampuan seseorang, baik yang kualitatif maupun yang kuantitatif." Jadi kompetensi guru adalah suatu hal yang menggambarkan kualifikasi atau kemampuan guru dalam melaksanakan tugas keprofesionalan.

Kompetensi merupakan gambaran hakikat kualitatif dari perilaku seseorang. Menurut Lefrancois kompetensi merupakan kapasitas untuk melakukan sesuatu yang dihasilkan dari proses belajar, selama proses belajar stimulus akan bergabung dengan isi memori dan menyebabkan terjadinya perubahan kapasitas untuk melakukan sesuatu. Apabila individu sukses mempelajari cara melakukan satu pekerjaaan yang kompleks dari sebelumnya, maka pada diri individu tersebut pasti sudah terjadi perubahan kompetensi.

Perubahan kompetensi tidak akan tampak apabila selanjutnya tidak ada kepentingan atau kesempatan untuk melakukannya. Dengan demikian bisa diartikan bahwa kompetensi adalah berlangsung lama yang menyebabkan individu mampu melakukan kinerja tertentu.

Pemahaman akan istilah kompetensi tidak dapat dipisahkan dengan konsep tentang profesi. Dalam Dictionary of Education menyatakan bahwa : Profession is an occupation usually involving relatively long and Specialized preparation on the level of higher education and governed by its own code of etec; profession is one who his acquired a learned skill an conform to ethical standard of the profession in which he practice to skill." (Profesi adalah suatu jabatan atau pekerjaan yang pada umumnya meminta persiapan spesialisasi yang relatif lama di perguruan tinggi dan diatur oleh kode etik khusus. Profesi adalah seseorang yang memperoleh keahlian dan ketrampilan dan mampu menyesuaikan diri dengan standar etis sesuai dengan profesi dimana ia mempraktekan ketrampilan tersebut).

Kompetensi adalah suatu kemampuan untuk melaksanakan atau melakukan suatu pekerjaan atau tugas yang dilandasi atas keterampilan dan pengetahuan serta didukung oleh sikap kerja yang dituntut oleh pekerjaan tersebut. Dengan demikian kompetensi menunjukan keterampilan atau suatu bidang tertentu bidang yang dicirikan oleh profesionalisme dalam suatu bidang 
tertentu sebagai sesuatu yang terpenting dalam bidang pekerjaan tersebut.

Terdapat lima karakristik kompetensi yang dikemukakan oleh Spencer yang dikutip oleh Wibowo, dikatakan :

1) Motif adalah sesuatu yang secara konsisten dipikirkan atau diinginkan orang yang menyebabkan tindakan.

2) Motif mendorong, mengarahkan, dan memilih perilaku menuju tindakan atau arahkan, dan memilih perilaku menuju tindakan atau tujuan tertentu. Sifat adalah karakteristik fisik dan respons yang konsisten terhadap situasi atau informasi.

3) Konsep diri adalah sikap, niali-nilai, atau citra diri seseorang. Percaya diri merupakan keyakinan orang bahwa merek adapat efektif dalam hampir setiap situasi.

4) Pengetahuan adalah informasi yang dimiliki orang dalam bidang spesifik. Pengetahuan adalah kompetensi yang kompleks.

5) Keterampilan adalah kemampuan mengerjakan tugas fisik atau mental tertentu. Kompetensi mental atau keterampilan kognitif termasuk berpikir analitis dan konseptual.

Kompetensi diartikan oleh Cowell, sebagai suatu keterampilan/kemahiran yang bersifat aktif. Kompetensi dikategorikan mulai dari tingkat sederhana atau dasar hingga lebih sulit atau kompleks yang pada gilirannya akan berhubungan dengan proses penyusunan bahan atau pengalaman belajar, yang lazimnya terdiri dari: (I) penguasan minimal kompetensi dasar, (2) praktik kompetensi dasar, dan (3) penambahan penyempurnaan atau pengembangan terhadap kompetensi atau keterampilan. Ketiga proses tersebut dapat terus berlanjut selama masih ada kesempatan untuk melakukan penyempurnaan atau pengembangan kompetensinya.

Berdasarkan uraian di atas, maka dapat disimpulkan bahwa kompetensi merupakan satu kesatuan yang utuh yang menggambarkan potensi, pengetahuan, keterampilan, dan sikap yang dinilai, yang terkait dengan profesi tertentu berkenaan dengan bagian bagian yang dapat diaktualisasikan dan diwujudkan dalam bentuk tindakan atau kinerja untuk menjalankan profesi tertentu. Berdasarkan Peraturan Pemerintah RI Nomor 19 tahun 2005 tentang Standar Nasional Pendidikan, Pasal 28 dinyatakan bahwa : Pendidik harus memiliki kualifikasi akademik dan kompetensi sebagai agen pembelajaran, sehat jasmani dan rohani, serta memiliki kemampuan untuk mewujudkan tujuan pendidikan nasional.

Kualifikasi akademik adalah tingkat pendidikan minimal yang harus dipenuhi oleh seorang pendidik yang dibuktikan dengan ijazah dan/atau sertiflkat keahlian yang relevan sesuai ketentuan perundang-undangan yang berlaku. Kompetensi sebagai agen pembelajaran pada jenjang pendidikan dasar dan menengah meliputi: kompetensi pedagogik, kompetensi kepribadian, kompetensi profesional, dan kompetensi sosial.

\section{Kerangka Pikir/ Kerangka Konsep}

Pengelolaan sumber daya manusia tentang pendidikan dan pelatihan dimana pada intinya bahwa pelatihan dimaksudkan untuk membantu meningkatkan kemampuan para pegawai dalam melaksanakan tugas sekarang, sedangkan pendidikan lebih berorientasi pada peningkatan kemampuan untuk melaksanakan tugas baru dimana yang akan datang. 
Kompetensi menyangkut kewenangan setiap individu untuk melakukan tugas dan mengambil keputusan sesuai dengan perannya dalam organisasi yang relevan dengan keahlian, pengetahuan, dan kemampuan yang dimiliki. Kompetensi yang dimiliki guru harus mampu mendukung pelaksanaan strategi organisasi dan mampu mendukung setiap perubahan yang dilakukan demi terciptanya strategi organisasi dan mampu mendukung setiap perubahan yang dilakukan demi terciptanya keberhasilan suatu organisasi.

\section{METODE PENELITIAN}

a. Teknik Analisis

Dalam penelitian ini, peneliti menggunakan analisis data seperti yang dikemukakan Miles dan Huberman bahwa aktivitas dalam analisa data dalam penelitian kualitatif dilakukan secara interaktif dan berlangsung secara terus menerus sampai tuntas, sehingga datanya sudah jenuh. Aktivitas dalam analisa data, yaitu 1) reduksi data (data reduction), 2) penyajian data (data display), dan 3) menarik kesimpulan/verifikasi (conclusion drawing/verification).

1. Reduksi Data

Pada tahap kegiatan reduksi data yang harus dilakukan peneliti adalah: meyeleksi, memfokuskan, menyederhanakan, mengabstraksikan dan mentrans-formasikan data hasil temuan dan catatan yang diperoleh di lapangan. Reduksi data ini dimaksudkan agar data dapat dikelompokkan, diseleksi, pemfokusan, penajaman pengorganisasian agar dapat ditarik kesimpulan. Reduksi data dilakukan dalam upaya menetapkan mana data yang dibutuhkan dan mana yang tidak, selanjutnya ke arah mana penelitian akan difokuskan.

\section{Penyajian Data}

Selanjutnya data dikelompokan atau diklasifikasikan sesuai dengan sub masalah yang dibahas dan kemudian disajikan untuk diinterpretasikan dengan analisa yang mendalam dan teliti agar sesuai dengan keadaan sebenarnya. Setelah data tereduksi dan disajikan dengan interpretasi peneliti, Pada tahap kegiatan penyajian data, yang harus dilakukan oleh peneliti adalah menampilkan sejumlah informasi yang telah disusun secara sistematis oleh peneliti berdasarkan data konkrit yang diperoleh dari lapangan, maka langkah terakhir menarik kesimpulan atau verifikasi terhadap data-data tersebut yang berkaitan dengan upaya meningkatkan kompetensi guru melalui pendidikan dan pelatihan pada UPT SMP Negeri 2 Duampanua Kabupaten Pinrang.

3. Menarik Kesimpulan/Verifikasi

Sedangkan pada tahap kegiatan verifikasi, yang harus dilakukan oleh peneliti adalah menarik kesimpulan sesuai dengan hasil terakhir dari sebuah peristiwa yang diteliti dan merupakan informasi yang utuh dan mendalam. Analisis data dilakukan dengan cara menelaah seluruh data dan informasi yang telah terkumpul dari berbagai sumber atau informan yang diperoleh melalui wawancara, pengamatan di lapangan yang telah ditulis dan dokumendokumen yang telah didapat. Ada beberapa hal yang perlu diperhatikan dalam menganalisis data, yakni :

a. Perlu dilakukan cek and ricek jika terdapat hasil analisis yang contra common sesnse

b. Melakukan kaji ulang, meneliti untuk kemudian dijelaskan akan adanya beberapa kejanggalan temuan dan lain sebagainya, kemudian diformat dan dilakukan perbaikan sedemikian rupa 
sehingga diperoleh satu kesatuan yang mendasar.

\section{HASIL DAN PEMBAHASAN}

a. Analisis kebutuhan pelatihan (Taining Need Assessment)

Analisis kebutuhan pelatihan (Taining Need Assessment) meliputi tiga hal yaitu analisis organisasi, analisis pekerjaan dan analisis pribadi. Kepala sekolah melakukan beberapa langkah dalam menganalisis kebutuhan yaitu menetapkan sasaran dalam pelaksanaan program terutama anggaran dan sarana fasilitas pendukung yang lainnya dan juga melibatkan semua guru untuk sharing informasi tentang bentuk program pelatihan yang dibutuhkan oleh guru dan pihak sekolah juga memberikan angket untuk dapat menjadi ukuran tentang apa yang telah dilaksanakan oleh guru.

\section{b. Menetapkan tujuan pelatihan}

Pihak sekolah berorientasi pada perubahan kualitas kinerja guru dalam pembelajaranselain peningkatan kualitas kompetensi juga agar terjadi perubahan pola pikir (mindset) guru dalam mempersiapkan pembelajaran, melaksanakan pembelajaran, dan mengevaluasi hasil pembelajaran.

\section{c. Pengembangan kurikulum}

Pengembangan kurikulum di UPT SMP Negeri 2 Duampanua meliputi penetapan kurikulum yang disusun dalam bentuk modul yang diturunkan dari standar kompetensi guru.

\section{d. Persiapan pelaksanaan diklat}

Persiapan pelaksanaan diklat yang dilakukan yaitu meliputi: menyusun silabus dan jadwal diklat berdasarkan sasaran dan program pelatihan, menghubungi pelajar/ pelatih, penyusunan materi pelatihan serta penyediaan bahan referensi, dan penyiapan tempat.

\section{e. Pelaksanaan pendidikan dan pelatihan}

Pelaksanaan pendidikan dan pelatihan pihak sekolah melakukan pembagian tugas dan penanggung jawab setiap kegiatan pelatihan berdasarkan rapat bersama, dan juga menyiapkan sarana prasarana yangdapat memberi kemudahan kepada peserta dalam proses pelatihan.

\section{f. Evaluasi-evaluasi diklat}

Evaluasi-evaluasi diklat yang dilakukan oleh UPT SMP Negeri 2 Duampanua melalui dua tahap evaluasi yaitu evaluasi terhadap proses dan evaluasi terhadap hasil tidak berkesinambungan dan penyelenggaraannya hanya ditempat pelatihan saja, dan tidak disertai dengan tindak lanjut bagaimana penerapan kemampuan yang telah diperoleh dalam upaya pemanfaatan kemampuan itu benar-benar dikuasi secara profesional.

\section{PENUTUP}

\section{a. Simpulan}

Setelah melakukan analisis data yang terkumpul dari hasil wawancara, dokumentasi dan observasi, dapat disimpulkan sebagai berikut :

1. Analisis kebutuhan pelatihan (Taining Need Assessment) meliputi tiga hal yaitu analisis organisasi, analisis pekerjaan dan analisis pribadi. Kepala sekolah melakukan beberapa langkah dalam menganalisis kebutuhan yaitu menetapkan sasaran dalam pelaksanaan program terutama anggaran dan sarana fasilitas pendukung yang lainnya dan juga melibatkan semua guru untuk sharing informasi tentang bentuk program pelatihan yang dibutuhkan oleh guru 
dan pihak sekolah juga memberikan angket untuk dapat menjadi ukuran tentang apa yang telah dilaksanakan oleh guru.

2. Menetapkan tujuan pelatihan, pihak sekolah berorientasi pada perubahan kualitas kinerja guru dalam pembelajaran selain peningkatan kualitas kompetensi juga agar terjadi perubahan pola pikir (mindset) guru dalam mempersiapkan pembelajaran, melaksanakan pembelajaran, dan mengevaluasi hasil pembelajaran.

3. Pengembangan kurikulum di UPT SMP Negeri 2 Duampanua meliputi penetapan kurikulum yang disusun dalam bentuk modul yang diturunkan dari standar kompetensi guru.

4. Persiapan pelaksanaan diklat yang dilakukan yaitu meliputi:menyusun silabus dan jadwal diklat berdasarkan sasaran dan program pelatihan, menghubungi pelajar/ pelatih, penyusunan materi pelatihan serta penyediaan bahan referensi, dan penyiapan tempat.

5. Pelaksanaan pendidikan dan pelatihan pihak sekolah melakukan pembagian tugas dan penanggung jawab setiap kegiatan pelatihanberdasarkan rapat bersama, dan juga menyiapkan sarana prasarana yang dapat memberi kemudahan kepada peserta dalam proses pelatihan.

6. Evaluasi-evaluasi diklat yang dilakukan oleh UPT SMP Negeri 2 Duampanua melalui dua tahap evaluasi yaitu evaluasi terhadap proses dan evaluasi terhadap hasil tidak berkesinambungan dan penyelenggaraannya hanya di tempat pelatihan saja, dan tidak disertai dengan tindak lanjut bagaimana penerapan kemampuan yang telah diperoleh dalam upaya pemanfaatan kemampuan itu benar-benar dikuasi secara profesional.

\section{b. Saran}

Berdasarkan hasil penelitian diatas dapat dikemukakan beberapa saran terkait Implementasi pendidikan dan pelatihan dalam meningkatkan kompetensi guru di UPT SMP Negeri 2 Duampanua sebagai berikut:

1. Penyelenggaraan pendidikan dan pelatihan seyogyanya mengakomodasi harapan para guru di lapangan sesuai dengan need assessment, khususnya berkaitan dengan substansi materi pelatihan dan durasi waktu pelatihan, sehingga kompetensi para peserta pelatihan menunjukkan peningkatan sesuai dengan tujuan yang harus dicapai.

2. Sebaiknya ada sistem evaluasi yang dilakukan secara berkala dalam setiap program pelatihan yang telah dilaksanakan dan ditentukan kriteria keberhasilan yang jelas untuk mengukur kinerja pencapaian terhadap program yang telah dilaksanakan sehingga ada kejelasan tentang kompetensi yang belum dan sudah dapat dicapai dari program tersebut.

3. Peneliti/akademisi. Hendaknya hasil penelitian ini dapat dijadikan referensi dalam rangka mengkaji bidang ekonomi yang relevan khususnya yang menyangkut pendidikan, pelatihan dan kompetensi guru. 


\section{Daftar Pustaka}

Agus Salim. 2001. Teori dan Paradigma Penelitian Sosial, Yogyakarta: Tiara Wacana.

Agus Tulus. 1996. Manajemen Sumber Daya Manusia, Jakarta: PT. GramediaPustaka.

Alisuf Sabri. 1992 Mimbar Agama dan Budaya, Jakarta: Pusat Penelitian dan Pengabdian Pada Masyarakat IAIN.

Asrorun Niam Sholeh, 2006. Membangun Profesionalitas Guru, Jakarta: Elsas.

Augene Mckenna \& Nic Beech. 2000. Manajemen Sumber Daya Manusia, Yokyakarta :Andi

Bungin. 2007. Penelitian Kualitatif, Jakarta: Prenada Media Grup.

Derek Torrington \& Tan ChweeHuat, 1994.Human Resource Management for Southeast Asia, Singapore : Simon \&schuster.

E.Mulyasa. 2001. Menjadi Kepala Sekolah Profesional dalam Konteks Mensukseskan MBS dan KBK, Bandung: RemajaRosdakarya.

E.Mulyasa. 2008. Standar Kompetensi dart Sertifikasi Guru, PT. Remaja RosdaKarya: Bandung.

E.Mulyasa. Standar Kompetensi dan Sertifikasi Guru, Bandung: PT Remaja Rosdakarya

GauzaliSaydam. 1996. Manajemen Sumber Daya Manusia, Jakarta: BumiAksara.

Good Carter V. 1973. Dectionary of Eduucation, third edition, (Mc. Graw-Hill, Book Company, New York.

Guy R. Lefrancois. I995. Theories of Human Learning.Kro: Kros Report.

Idochidan Hidayat Amir. 2006. Depdiknas. Standar Kompetensi Kepala madrasah TK,SD, 5MP. SMA, SMK \& $S L B$, Jakarta : BP. CiptaKarya.
Indah PujiHartatik. 2014.Pengembangan $S D M$, Yokyakarta : Laksana.

Jusmaliani, 2004.Pengelolaan Sumber Daya Insani, Jakarta :Bumi Aksara.

Kasmir.2016. Manajemen Sumber Daya Manusia Teori dan Praktik. Jakarta :Rajawali Pers.

Komarudin Sasradipoera, 2006. Pengembangan dan Pelatihan, Bandung: Kappa Sigma

Kunandar. 2011. Guru Profesional Implementasi Kurikulum Tingkat Satuan Pendidikan (KTSP) dan Sukses dalam Sertifikasi Guru. Jakarta: PT Rajagrafindo Persada

Lexy J Moleong, 2002. Metodologi Penelitian Kualitatif, Bandung: Remaja RosdaKarya

Made Pidarta. 1998. Manajemen Pendidikan Indonesia, Jakarta : PT. BinaAksara.

Malayu S.P Hasibuan, 2014. Manajemen Sumber Daya Manusia, Jakarta: PT BumiAksara.

Mansur Muslich. 2007. KTSP Pembelajaran Berbasis Kompetensi Dan Kontekstual: Panduan Bagi Guru, Kepala Sekolah, Dan Pengawas Sekolah, Jakarta: Bumi Aksara, 2007.

Muhibbin Syah. 2007. Psikoiogi Pendidikan dengan Pendekatan Baru, Bandung: PT. Remaja Rosdakarya.

N. Cowell, 1988. Buku Pegangan Para Penulis Paket Belajar. Jakarta: Proyek Pengembangan dan Tenaga Kependidikan, Depdikbud

Nana Sudjana, 1999. Tuntunan Penyusunan Karya Ilmiah, Bandung: Sinar Baru Algesindo.

Nurul Ulfatin \& Teguh Triwianto. 2016. Manajemen Sumber Daya Manusia Bidang Pendidikan. Jakarta :Rajawali pers. 
Rasmianto, 2003. Kepemimpinan Kepala Sekolah Berwawasan VisionerTransformatszalam Otonorni Pendidikan, dalamJ urnaleLHarokah. Malang: UIIS.

Sadili Samsudin, 2006. Manajemen Sumber Daya Manusia, Bandung :Pustaka Setia, 2006

Sedarmayanti.2016. Manajemen Sumber Daya Manusia Reformasi Birokrasi dan Manajemen Pegawai Negeri Sipil. Bandung : PT Revika Aditama.

Soekidjo Notoatmodjo, 1998. Pengembangan Sumber Daya Manusia, Jakarta: PT. Rinekacipta.

Soetrisno \& Rita Nanafie, 2007.Filsafat Ilmu dan Metodologi Penelitian, Andi, Yogyakarta.

Sondang P. Siagian. 1992. Manajemen Sumber Daya Manusia, Jakarta : Bumiaksara.

Standar Nasional Pendidikan (SNP), 2006. Jakarta: AsaMandiri.

Sudarwan Danim. 2002. Inovasi Pendidikan :Dalam Upaya Meningkatkan Profesionalisme Tenaga Kependidikan, Bandung : PustakaSetia.

Sugiono, 2014. Metode Penelitian Pendidikan: Pendekatan Kualitatif, Kuantitatif Dan $R$ \& D, Bandung: Alfabeta.

Suharsimi Arikunto, 2002. Prosedur Penelitian Suatu Pendekatan Praktek, Jakarta: RinekaCipta.

Susilo Martoyo. 1985. Manajemen Sumber Daya Manusia, Yogyakarta: BPFE.

Suyantodan DjihadHisyam, 2000.Refleksi dan Reformasi Pendidikan Indonesia Memasuki Millenium III, Yogyakarta: AdiCita.

Soekidjo Notoatmodjo, 1998. Pengembangan Sumber Daya Manusia, Jakarta: PT. Rinekacipta.
Sadili Samsudin, 2006. Manajemen Sumber Daya Manusia, Bandung : Pustaka Setia.

Undang-undang Guru danDosen UU RI no 14 tahun 2005. 2010. Jakarta: SinarGrafika

UU No. 14 tentang Guru danDosendan PP No. 19 tahun 2005 pasal 28

UU RI No. 20 Tahun 2005 tentang 2006.Sistem Pendidikan Nasional, Bandung : Citra Umbara, 2006

VeithzalRivai, 2004. Manajemen Sumber Daya Manusia untuk Perusahaan : Dari Teorike Praktik, Jakarta : Rajawali Pers.

Wahyosumidjo. 2003. Kepemimpinan Kepala Sekolah Tinjauan Teoritik dan Permasalahannya, : Jakarta : Raja Grafindo Persada.

Wibowo. 2007. Manajemen Kinerja, Jakarta : PT. Raja GrafindoPersada. 